\title{
KESULITAN BELAJAR KETERAMPILAN MENULIS TEKS ANEKDOT \\ SISWA X IPS 2 SMA NEGERI 2 PERCUT SEI TUAN MEDAN \\ TAHUN PELAJARAN 2017/2018
}

\author{
Monika (monikgemini11@gmail.com) \\ Dr. Afnita, S.Pd., M.Pd.
}

\begin{abstract}
Abstrak
Penelitian ini mendeskripsikan (1) kesulitan belajar keterampilan menulis teks anekdot dalam pembelajaran bahasa Indonesia yang dialami oleh siswa kelas X IPS 2 SMA Negeri 2 Percut Sei Tuan Medan tahun pelajaran 2017/2018 dan (2) faktor yang menyebabkan kesulitan belajar keterampilan menulis teks anekdot dalam pembelajaran bahasa Indonesia yang dialami oleh siswa kelas X IPS 2 SMA Negeri 2 Percut Sei Tuan Medan tahun pelajaran 2017/2018. Penelitian ini menggunakan rancangan deskriptif kulaitatif. Subjek penelitian ini adalah siswa kelas X IPS 2 dan guru bahasa Indonesia. Objek penelitian ini adalah kesulitan dan faktor-faktor penyebab kesulitan belajar dalam keterampilan menulis teks anekdot.

Hasil penelitian ini menunjukkan bahwa (1) ada tujuh kesulitan belajar dalam menulis teks anekdot yang dialami oleh siswa kelas X IPS 2. Kesulitan tersebut yaitu (a) kesulitan dalam menentukan tema yang menarik, (b) kesulitan mengawali dan mengembangkan ide dan gagasan ke dalam sebuah teks (c) kesulitan mencari inspirasi karena siswa sering merasa "buntu" di tengah jalan, (d) kesulitan dalam menentukan kaidah kebahasaan, (e) kurang memahami mengenai struktur teks anekdot, (f) kesulitan mengunakan bahasa yang santun, dan (g) kesulitan menentukan kata sindiran yang sesuai dan tepat. (2) ada tiga faktor yang menyebabkan adanya kesulitan belajar. (a) faktor yang bersumber dari lingkungan sekolah, (b) faktor yang bersumber dari lingkungan keluarga, dan (c) faktor dari yang bersumber dari lingkungan masyarakat. Secara umum, siswa memiliki kesulitan belajar dan faktor penyebab kesulitan belajar dalam keterampilan menulis teks anekdot. Dengan adanya kesulitan dan faktor penyebab kesulitan belajar tersebut, guru diharapkan mampu mengatasi kesulitan yang dialami oleh siswa dan mengatasi faktor penyebab kesulitan belajar tersebut.
\end{abstract}

Kata Kunci: diagnosis, menulis, teks anekdot.

\section{PENDAHULUAN}

Kurikulum mempunyai kedudukan yang penting dalam seluruh proses pendidikan. Kurikulum menjadi penentu dalam pencapaian tujuan pendidikan. Dikatakan demikian, karena kurikulum merupakan suatu rencana yang memberi pedoman atau pegangan dalam proses kegiatan belajar mengajar. kurikulum 2013 merupakan adalah kurikulum yang berlaku 
dalam Sistem Pendidikan Indonesia. Kurikulum ini merupakan kurikulum tetap diterapkan oleh pemerintah untuk menggantikan Kurikulum 2006 (yang sering disebut sebagai Kurikulum Tingkat Satuan Pendidikan) yang telah berlaku selama kurang lebih 6 tahun. Menurut Mulyasa (2013:99) menyatakan bahwa tema Kurikulum 2013 adalah menghasilkan insan Indonesia yang produktif, kreatif, inovatif, efektif, melalui penguatan sikap, keterampilan, dan pengetahuan yang terintegrasi. Salah satu materi pembelajaran bahasa Indonesia di tingkat SMA yang terdapat dalam silabus Kurikulum 2013 kelas X adalah materi yang berupa teks anekdot. Teks anekdot merupakan salah satu genre teks yang wajib dipelajari siswa SMA/MA dalam Kurikulum 2013 mengarah pada kemunculan berbagai efek positif bagi siswa. Materi memproduksi teks anekdot ini sesuai dengan tema kurikulum 2013 yaitu guna membentuk siswa yang produktif dan kreatif. Maka dari itu, keterampilan pembelajaran menulis teks anekdot penting untuk dikuasai oleh siswa karena tercantum dalam kurikulum dan kurikulum mengharuskan siswa dapat menguasai keterampilan menulis teks anekdot.

Dari sekian banyak keterampilan berbahasa yang harus dikuasai siswa, keterampilan menulis diakui oleh siswa kelas X IPS2 merupakan yang sangat sulit karena mengintegrasikan berbagai kemampuan berbahasa seperti penguasaan kosakata, ejaan, penentuan topik, tema, penyusunan kalimat dan paragraf. Keterampilan menulis merupakan keterampilan yang sangat kompleks, siswa tidak hanya menuangkan ide tetapi, siswa juga dituntut untuk menuangkan gagasan, konsep, perasaan, dan kemauan. Menurut Tarigan (2008:2) keterampilan menulis dibutuhkan waktu yang lama dan latihan intensif. Keterampilan menulis bisa dikatakan suatu ciri dari orang yang terpelajar atau dari bangsa yang terpelajar. Maka dari itu, kebanyakan siswa mengangap keterampilan menulis sangat sulit khususnya bagi siswa kelas X IPS 2 SMA Negeri 2 Percut Sei Tuan Medan. Pada umumnya, siswa tidak bisa mengkomunikasikan maksudnya lewat tulisan secara baik. hal tersebut di dukung oleh pernyataan Akhadiah (2003: 2) yang menyatakan, bahwa menulis merupakan keterampilan berbahasa yang paling rumit. Hal ini disebabkan karena menulis melibatkan berbagai keterampilan lainnya, diantaranya kemampuan menyusun pikiran dan perasaan dengan menggunakan kata-kata dalam bentuk kalimat yang tepat sesuai dengan struktur dan kaidah tata bahasa.

Sebagian guru pengampu mata pelajaran bahasa Indonesia di SMA mengakui bahwa keterampilan menulis sangat sulit untuk dikuasai dengan baik oleh siswa karena menulis merupakai keterampilan yang berada dalam tingkat kesulitan yang paling tinggi. Selain itu, 
guru juga lebih banyak menggunakan metode ceramah dalam pembelajaran menulis. Seharusnya agar siswa mampu menulis dengan baik, guru tidak hanya memberikan penyampaian materi tetapi juga langsung membimbing siswa dengan mempraktikkan langsung keterampilan menulis itu sendiri. Sekalipun keterampilan menulis merupakan keterampilan yang paling sulit, namun kurikulum mengharuskan siswa untuk dapat mengusainya. Sementara permasalahan yang sekarang muncul adalah siswa mengalami kesulitan dalam pembelajaran keterampilan menulis.

Masalah kesulitan belajar dalam pembelajaran menulis pun terlihat pada siswa kelas X IPS 2 SMA Negeri 2 Percut Sei Tuan Medan. Berdasarkan hasil wawancara dengan guru mata pelajaran bahasa Indonesia kelas X (ibu Zulfahanny Nasution S.Pd.) menyatakan bahwa nilai keterampilan menulis kelas X IPS 2 sangat tergolong rendah ini terbukti dengan hampir $80 \%$ sebagian siswa dari kelas X IPS 2 banyak tidak mencapai nilai ketuntasan belajar menulis di SMA ini. Hal ini menunjukkan bahwa pembelajaran keterampilan menulis masih sangat jauh dari tujuan yang telah ditargetkan oleh kurikulum 2013. Berdasarkan hasil wawancara tersebut, peneliti menemukan beberapa masalah yaitu, pertama, siswa memiliki kesulitan dalam pembelajaran menulis, dan kedua, guru belum melakukan diagnosa untuk mengetahui kesulitan belajar menulis siswa. Selain itu, berdasarkan informasi yang didapat dari hasil wawancara beberapa siswa kelas X IPS 2 (Lulu Khairunnisah, Uswatun Hasanah, Nisya Dhara Anjeli dan Gita Eka Putri) mereka menyatakan bahwa mereka sangat kesulitan dalam pembelajaran menulis terutama dalam menuangkan gagasan atau ide ke dalam bentuk tulisan serta guru cendrung menggunakan metode ceramah dalam pembelajaran bahasa Indonesia.

Menyadari adanya kesulitan belajar pada siswa maka kesulitan itu perlu untuk diteliti. Agar dapat diketahui secara pasti hal-hal yang menjadi kesulitan bagi siswa maka perlu dilakukan diagonis. Dengan melakukan diagnosis, dapat ditentukan tindak lanjut yang bisa dilakukan untuk mengatasi kesulitan belajar tersebut. Dalam Kamus Besar Bahasa Indonesia, diagnosis adalah penentuan jenis penyakit dengan cara meneliti atau memeriksa gejala-gejalanya. diagnosis adalah suatu analisis terhadap kelainan atau salah penyesuaian dari pola gejala-gejalanya atau diagnosis merupakan proses pemeriksaan terhadap hal-hal yang dipandang tidak beres atau bermasalah. Penyakit yang dimaksud dalam hal ini adalah adalah kesulitan belajar menulis yang dialami siswa. Pentingnya mendiagnosis kesulitan belajar menulis siswa adalah untuk memberikan 
penjabaran mengenai kesulitan-kesulitan yang dialami siswa. Dengan mengetahui kesulitan-kesulitan tersebut, guru diharapkan mampu memberikan solusi kepada siswa sehingga bisa mengatasi kesulitan yang dialami.

Salah satu kompetensi yang harus dimiliki siswa dalam Kurikulum 2013 Bahasa Indonesia kelas X SMA adalah siswa mampu memproduksi teks anekdot baik lisan maupun tulisan. Namun, pada kenyataannya masih banyak siswa yang tidak mampu memproduksi teks anekdot, terutama dalam bentuk tulisan. Itulah sebabnya kegiatan menulis teks anekdot bukanlah hal yang mudah bagi siswa termasuk siswa kelas X IPS 2 SMA Negeri 2 Percut Sei Tuan Medan, karena teks anekdot dalam kurikulum 2013 masih terbilang baru dalam pembelajaran bahasa Indonesia dan baru diperkenalkan mulai dari jenjang SMS/MA/SMK. Hal tersebutlah yang membuat peneliti tertarik untuk melakukan penelitian mengenai diagnosis belajar keterampilan menulis teks anekdot. Selain itu, yang membuat peneliti tertarik melakukan penelitian ini di SMA Negeri 2 Percut Sei Tuan Medan karena sekolah ini masih terbilang baru beroperasional dalam pendidikan yaitu berdiri pada tanggal 06 Juli 2015. Oleh karena itu, penelitian ini diberi judul “ Kesulitan Belajar Keterampilan Menulis Teks Anekdot Siswa X SMA Negeri 2 Percut Sei Tuan Medan Tahun Pelajaran 2017/2018“. Pembelajaran bahasa Indonesia pada kurikulum 2013 mempelajari teks yang berbeda-beda pada setiap KD yang telah ditetapkan di kurikulum 2013. Teks-teks tersebut terbagi pada kompetensi-kompetensi yang tertuang dalam silabus. Salah satu kompetensi dasar (KD) yang harus dicapai dalam pelajaran bahasa Indonesia menurut kurikulum 2013 untuk siswa kelas X SMA adalah menulis teks anekdot.

Dalam melakukan penelitian ini, peneliti belum menemukan penelitian mendiagnosis kesulitan belajar keterampilan menulis teks anekdot dalam pembelajaran bahasa Indonesia. Namun peneliti menemukan beberapa penelitian sejenis yang memiliki ciri khas tersendiri, tetapi berbeda dengan penelitian yang dirancang. Adapun penelitian yang sejenis terkait dengan penelitian ini adalah sebagai berikut.

Sebelum penelitian ini direncanakan, peneliti menemukan hasil penelitian yang juga meneliti mengenai diagnosis kesulitan belajar dalam pembelajaran bahasa Indonesia. Penelitian tersebut dilakukan oleh I Putu Mas Dewantara (2012) dengan judul "Identifikasi Faktor Penyebab Kesulitan Belajar Keterampilan Berbicara dan Strategi Guru untuk Mengatasinya”. Penelitian ini menganalisa faktor penyebab kesulitan belajar keterampilan berbicara dan strategi guru untuk mengatasinya. 
Penelitian kedua dilakukan oleh Indra Nugrahayu Taufik (2014) dengan judul “ Kajian Kesulitan Belajar Menulis Pada Siswa Kelas III Sekolah Dasar Negeri 2 Cihalimun Kec. Kertasari Kab. Bandung”. Penelitian ini menganalisa tentang kesulitan-kesulitan dalam memproduksi tulisan grafemis. Dari dua penelitian yang ada, sudah jelas berbeda dengan penelitian ini. Sebab penelitian ini belum ada yang mengkaji. Maka dari itu, perlu dilakukan penelitian untuk mengkaji permasalah yang peneliti angkat.

Berdasarkan latar belakang di atas, permasalahan yang hendak dikaji dalam penelitian ini adalah (1) apa saja kesulitan belajar keterampilan menulis teks anekdot dalam pembelajaran bahasa Indonesia yang dialami siswa kelas X IPS 2 SMA Negeri 2 Percut Sei Tuan Medan? (2) apa saja faktor yang menyebabkan kesulitan belajar keterampilan menulis teks anekdot dalam pembelajaran bahasa Indonesia yang dialami oleh siswa kelas X IPS 2 SMA Negeri 2 Percut Sei Tuan Medan?. Tujuan yang ingin dicapai dicapai dalam penelitian ini diharapkan mampu mendeskripsikan (1) kesulitan belajar keterampilan menulis teks anekdot dalam pembelajaran bahasa Indonesia yang dialami oleh siswa kelas X IPS 2 SMA Negeri 2 Percut Sei Tuan Medan dan (2) faktor yang menyebabkan kesulitan belajar menulis teks anekdot dalam pembelajaran bahasa Indonesia yang dialami oleh siswa kelas X IPS 2 SMA Negeri 2 Percut Sei Tuan Medan.

Adapun manfaat yang diharapkan dari hasil penelitian ini adalah (1) secara teoretis, hasil penelitian ini dapat memberikan sumbangan informasi tentang kesulitan belajar, khususnya kesulitan menulis teks anekdot. (2) Secara praktis, hasil penelitian ini ditujukan untuk beberapa pihak yang memiliki kepentingan terkait dengan teks anekdot. Pihakpihak tersebut diantaranya guru bahasa Indonesia, mahasiswa calon guru, peneliti lain, dan sekolah.

\section{METODE PENELITIAN}

Rancangan penelitian yang digunakan dalam penelitian ini adalah rancangan deskriptif kualitatif. Subjek penelitian ini adalah siswa kelas XIPS 2 dan guru mata pelajaran bahasa Indonesia kelas X IPS 2 SMA Negeri 2 Percut Sei Tuan Medan, sedangkan objek penelitian ini adalah kesulitan dan faktor- faktor penyebab kesulitan belajar dalam keterampilan menulis teks anekdot siswa kelas X IPS 2 SMA 2 percut Sei Tuan Medan. Metode pengumpulan data dalam penelitian ini meliputi (1) metode observasi dan (2) metode wawancara. Dalam penelitian ini, metode observasi nonpartisipatif adalah metode yang digunakan karena peneliti ingin melihat situasi pelaksanaan pembelajaran dalam kegiatan menulis siswa kelas X IPS 
2 SMA Negeri 2 Percut Sei Tuan Medan dan melihat bagaimana guru membimbing siswa dalam proses pembelajaran yang alami tanpa ada intervensi dari peneliti. Serta peneliti juga melihat bagaimana guru membimbing sisiwanya dalam proses pembelajaran berlangsung terutama dalam tugas kegiatan menulis. Instrumen yang digunakan dalam metode observasi adalah lembar observasi/catatan lapangan. Penelitian ini juga menggunakan metode wawancara dalam pengumpulan data. Metode wawancara yang digunakan adalah wawancara terstruktur agar peneliti mendapatkan jawaban sesuai dengan yang diinginkan. Sejalan dengan pendapat Sugiyono (2007:9) yang menyatakan bahwa, "Untuk mendapat informasi yang lebih dalam tentang narasumber, maka peneliti dapat juga menggunakan wawancara terstruktur". Wawancara itu sendiri Menurut Maryaeni (2005;70) merupakan salah satu pengambilan data yang dilakukan melalui kegiatan komunikasi lisan dalam bentuk terstruktur, semi terstruktur, dan tak terstruktur. Metode wawancara ini dilakukan apabila sebuah kasus ketika diobservasi tidak dapat dipecahkan secara ilmiah dan memerlukan jawaban yang sebenarnya dari penutur itu sendiri.

Teknik analisis data yang digunakan dalam penelitian ini adalah teknik analisis deskriptif kualitatif menggunakan prosedur dengan model analisis Miles and Huberman (1984) (dalam Sugiyono, 2007:337) yang terdiri atas, pertama reduksi data (reduction data) yang dilakukan pemilihan hal-hal pokok, memfokuskan pada hal-hal penting, mencari temanya serta polanya dan membuang yang tidak perlu.

Kedua, penyajian data (data display) yang dilakukan dengan mengolah dan menganalisis data untuk memperoleh jawaban yang tepat yang sesuai dengan rumusan masalah. Dalam penyajian ini, data mengenai kesulitan belajar dan faktor- faktor penyebab kesulitan belajar keterampilan menulis teks anekdot dalam pembelajaran bahasa Indonesia di kelas XIPS2 SMA Negeri 2 Percut Sei Tuan Medan yang telah direduksi, akan diuraikan sedemikian rupa sehingga dapat ditemukan kesulitan dan faktor-faktor penyebab kesulitan belajar keterampilan menulis cerpen yang dialami oleh siswa kelas X IPS2 SMA Negeri 2 Percut Sei Tuan Medan.

Ketiga, penarikan simpulan/verifikasi (coclusion drawing), simpulan yang dikemukakan pada tahap awal didukung oleh adanya data yang valid, maka pembuatan simpulan adalah jawaban dari permasalahan yang sesuai dengan keadaan dan apa adanya. Hasil kegiatan itu berupa simpulan sementara. Oleh sebab itu, sebelum menyusun laporan penelitian, dilakukan pengecekan kembali keseluruhan proses untuk mendapatkan hasil analisis dan simpulan yang meyakinkan.

\section{HASIL PENELITIAN DAN PEMBAHASAN}


Hasil penelitian ini meliputi (1) kesulitan belajar keterampilan menulis teks anekdot dalam pembelajaran bahasa Indonesia siswa kelas X IPS 2 SMA Negeri 2 Percut Sei Tuan Medan, dan (2) faktor-faktor penyebab kesulitan belajar keterampilan menulis teks anekdot dalam pembelajaran bahasa Indonesia siswa kelas X IPS 2 SMA Negeri 2 Percut Sei Tuan Medan. Berikut dipaparkan hasil temuan diperoleh selama melaksanakan penelitian.

Ada beberapa kesulitan keterampilan menulis teks anekdot bertolak dari peristiwa yang dialami siswa. Kesulitan tersebut adalah sebagai berikut (1) kesulitan dalam menentukan tema yang menarik. Bagi siswa, menentukan tema yang menarik bukanlah hal yang mudah. Apalagi sebagian besar siswa tidak pernah menulis teks anekdot sebelumnya, karena siswa baru mengenal teks anekdot semenjak mulai jenjang SMA, oleh karena itu, ketika diminta untuk menentukan tema dalam menulis teks anekdot mereka mulai kebingungan mau menulis apa. (2) kesulitan mengawali dan mengembangkan ide dan gagasan ke dalam sebuah teks. Setelah mendapatkan tema yang menarik, seringkali siswa bingung untuk mengawali apa yang akan ditulis untuk dikembangkan menjadi cerita yang menarik, lucu dan penuh humor (3) kesulitan mencari inspirasi karena siswa sering merasa "buntu" di tengah jalan. Setelah mendapatkan tema cerita yang akan ditulis kemudian mengembangkan cerita tersebut menjadi cerita yang lucu dan menarik, seringkali kali di tengah-tengah cerita siswa sering buntu untuk melanjutkan cerita tersebut mereka tidak tau lagi apa yang harus ditulis lagi. (4) kesulitan dalam menentukan kaidah kebahasaan. Bagi siswa, menentukan kaidah kebahasaan dalam menulis teks anekdot bukanlah hal yang mudah. Mereka harus menentukan kaidah-kaidah yang sesuai dalam cerita yang ia tulis, hal ini membuat siswa agak kebingungan. (5) kurang memahami mengenai struktur teks anekdot. Salah satu yang membuat siswa kesulitan dalam menulis teks anekdot adalah siswa tidak memahami mengenai struktur teks anekdot. Mereka tidak paham apa saja struktur-struktur dalam teks anekdot, hal ini membuat mereka sedikit kesusahan dalam menulis teks anekdot. (6) kesulitan mengunakan bahasa yang santun. Dalam menentukan pilihan bahasa yang baik dan cocok dalam tulisannya siswa sedikit bingung dan susah dalam mengungkapkannya. Terkadang mereka merasa bahasa yang ia gunakan akan membuat pembaca tidak memahami apa yang ia tulis dalam cerita dan takut bahasanya tidak santun atau tidak baik. (7) kesulitan menentukan kata sindiran yang sesuai dan tepat. Dalam menulis teks anekdot, siswa sering merasa kesulitan dalam menuliskan katakata sindiran yang akan ia gunakan dalam ceritanya. Karena dalam menulis teks anekdot ceritanya harus bersifat humor, menyindir dan lelucon yang realistis. Dalam hal ini yang siswa lebih sering bingung dalam mennetukan kata-kata sindiran yang akan digunakan, ia selalu ragu-ragu dalam membuat kata-kata sindiran yang cocok dan sesuai agar pembaca 
merasa tertarik dan terhibur dalam cerita yang dibuat. Hal ini menjadi kesulitan tersendiri bagi siswa kelas X SMA Negeri 2 Percut Sei Tuan Medan.

Selain kesulitan, berdasarkan hasil penelitian yang telah dilakukan, didapatkan beberapa faktor penyebab dari kesulitan belajar keterampilan menulis teks anekdot yang dialami oleh siswa kelas X SMA Negeri 2 Percut Sei Tuan Medan dalam pembelajaran bahasa Indonesia. Faktor-faktor tersebut adalah sebagai berikut. (1) faktor yang bersumber dari keluarga. lingkungan keluarga sangat menentukan keberhasilan belajar siswa. Tidak bisa dipungkiri bahwa keluarga menjadi salah satu faktor penyebab kesulitan belajar yang muncul dari dalam diri siswa. Hal ini terjadi karena siswa tidak menghabiskan sebagian waktunya di sekolah melainkan di rumah. Bimbingan dan dukungan orang tua akan berpengaruh juga pada kemampuan siswa, tidak terkecuali kemampuan menulis. Selain itu, status ekomoni, status sosial, cara orang tua mendidik, kebiasaan dan suasana lingkungan keluarga ikut serta mendorong terhadap keberhasilan belajar. Jadi, jika tidak adanya dukungan maupun dorongan dari orang tua juga merupakan salah satu faktor penyebab kesulitan yang dialami oleh siswa dalam menulis teks anekdot. (2) faktor yang bersumber dari lingkungan sekolah. Sekolah sebagai lembaga pendidikan formal setelah keluarga dapat menjadi masalah pada umumnya, dan khususnya masalah kesulitan belajar pada siswa. Tidak terkecuali kesulitan dalam keterampilan menulis teks anekdot. Sebagai sebuah lembaga pendidikan, penting rasanya jika sekolah melaksanakan kegiatan yang bersifat akademis. Dalam hal ini yaitu mengadakan lomba menulis teks anekdot karena hal ini bisa menjadi salah satu tempat atau wadah bagi siswa untuk mengasah kemampuannya. Selain memberikan dukungan positif kepada siswa dengan mengadakan lomba menulis teks anekdot. Dukungan yang bisa dilakukan oleh sekolah yaitu dengan memastikan bahwa siswa tidak akan kesulitan dalam hal menemukan referensi atau bahan tulisan untuk menulis teks anekdot yang lucu dan penuh humor dengan berbagai tema yang akan dibuat misalnya bertemakan tentang politik, pendidikan, sosial dan lain-lain. Namun, sekolah belum pernah mengadakan iklim yang kondusif seperti mengadakan lomba menulis teks anekdot untuk mendorong minat siswa ataupun meningkatkan kemampuan siswa dalam keterampilan menulis utamanya menulis teks anekdot. Hal ini sangat bagus sekali dilakukan untuk menambah pengetahuan dan keterampilan siswa mengenai teks anekdot karena siswa baru mengenalnya pada tingkat SMA, dan teks anekdot ini termasuk pelajaran yang baru juga dalam pembelajaran bahasa Indonesia. faktor lain yang berasal dari lingkungan sekolah adalah suasana atau kondisi ruang belajar di sekolah. Hal ini juga sangat berpengaruh dalam ketenangan siswa dalam belajar terutama dalam keterampilan menulis. Karena ruang yang 
nyaman dan tenang itu akan membuat siswa lebih fokus untuk menulis dalam menungkan ideide yang ada di dalam pikirannya. Selain itu, faktor lain yang berasal dari lingkungan sekolah yaitu dari guru pengampu mata pelajaran bahasa Indonesia itu sendiri Berdasarkan hasil observasi, guru tidak membimbing siswa secara penuh dalam menulis teks anekdot. Hal ini menyebabkan siswa tidak tahu hal-hal yang benar dan salah dalam teks anekdot yang dibuat. Baik itu terkait dari segi struktur, kaidah kebahasaan, maupun isi dalam teks anekdot, dan (3) faktor yang bersumber dari lingkungan masyarakat. Faktor lingkungan masyarakat sangat berperan di dalam pembentukan kepribadian anak termasuk pula kemampuan/pengetahuannya. Siswa juga merupakan salah satu bagian dari lingkungan masyarakat tempatnya bermukim. Maka dari itu, tidaklah salah jika kesulitan belajar yang dialami oleh siswa merupakan dampak dari lingkungan masyarakat yang kurang mendukung. Ada banyak hal yang bisa diselenggarakan masyarakat untuk mendukung siswa dalam mengasah kemampuan akademiknya salah satunya yaitu menulis teks anekdot. Misalnya saja dengan menyelenggarakan lomba menulis teks anekdot antardesa, atau antar kecematan. Namun, sebagian besar siswa mengakui bahwa di lingkungan tempat mereka tinggal tidak pernah menyelenggarakan lomba-lomba yang berkaitan dengan menulis utamanya menulis teks ankedot. Hal ini pada akhirnya juga berpengaruh pada kemampuan siswa dalam menulis teks anekdot. Jika hal ini bisa dilakukan oleh lingkungan tempat tinggal siswa maka akan menambah tingkat kemampuan dan pengalaman siswa dalam menulis teks anekdot, dan akan memberikan kemudahan siswa dalam mengerjakan tugas menulis yang diberikan guru di sekolah nantinya.

Saat menulis teks ankedot yang bertolak dari peristiwa yang dialami oleh tokoh-tokoh yang terkenal, siswa mengalami beberapa kesulitan karena menulis merupakan salah satu kegiatan yang bersifat komplek. Hal ini sejalan dengan pendapat dengan Akhadiah , Ridwan dan Arsyad (1988:2) yang menyatakan bahwa "Tidaklah berlebihan jika dikatakan bahwa kemampuan menulis merupakan kemampuan yang kompleks, yang menuntut sejumlah pengetahuan dan keterampilan”. Serta Menulis membutuhkan keahlian dibidangnya, mulai dari kalimatnya yang dapat dipahami oleh pembaca dan menulis menuangkan apresiasi seseorang ke dalam berkarya sehingga tujuan keinginan penulis dapat diketahui oleh pembaca. Dengan demikian maka tidaklah salah jika siswa mengalami kesulitan saat menulis. Dalam hal ini, menulis teks anekdot bertolak dari peristiwa yang pernah dialami oleh tokoh-tokoh yang terkenal.

Berdasarkan data hasil penelitian, ada beberapa kesulitan belajar keterampilan menulis teks ankedot siswa kelas X IPS 2 SMA Negeri 2 Percut Sei Tuan Medan yaitu: (1) 
kesulitan dalam menentukan tema yang menarik, (2) kesulitan mengawali dan mengembangkan ide dan gagasan ke dalam sebuah teks, (3) kesulitan mencari inspirasi karena siswa sering merasa "buntu" di tengah jalan, (4) kesulitan dalam menentukan kaidah kebahasaan, (5) kurang memahami mengenai struktur teks anekdot, (6) kesulitan mengunakan bahasa yang santun, dan (7) kesulitan menentukan kata sindiran yang sesuai dan tepat. (2) ada tiga faktor yang menyebakan adanya kesulitan belajar. (a) faktor yang bersumber dari lingkungan sekolah, (b) faktor yaang bersumber dari lingkungan keluarga, dan (c) faktor dari yang bersumber dari lingkungan masyarakat. Kesulitan tersebut juga tergambar pada pendapat Rachmawati (2014: 3) yang mengemukan bahwa ada beberapa kesulitan yang dialami saat menulis. Kesulitan tersebut diantaranya yaitu: (1) siswa merasa kesulitan menuangkan ide, dan (2) kegiatan menulis membosankan sehingga siswa kurang merespon yang baik. selain itu pendapat dari Wardani, Fuady dan Andayani (2016) yang mengemukakan bahwa ada beberapa kesulitan yang dialami saat menuli teks anekdot. Kesulitan tersebuat diantaranya yaitu: (1) siswa sulit mencari ide yang menarik, (2) siswa sering tertukar menempatkan urutan bagian teks berdasarkan struktur, (3) teks yang dihasilkan siswa sering tidak lengkap strukturnya, dan (4) keaktifan siswa pada pembelajaran menulis masih kurang yaitu hanya $40 \%$ sisa yang aktif selama pembelajaran. Maka tidaklah salah jika siswa kelas X IPS 2 SMA Negeri 2 Percut Sei Tuan Medan mengalami kesulitan yang serupa.

Kesulitan pertama yang dialami oleh siswa saat menulis teks anekdot yaitu kesulitan dalam menantukan tema yang menarik. Hal ini dibuktikan oleh hasil wawancara kepada siswa yang menunjukkan bahwa siswa memang mengalami kesulitan saat akan menentukan tema yang menarik untuk dibuat ke dalam teks anekdot yang lucu dan humor. Senada dengan pendapat Gunatama (2005:76) yang mengatakan bahwa "Kedudukan tema sangatlah penting dalam sebuah karya sastra karena semua unsur sastra sistem oprasionalnya mengacu pada tema tersebut." Selain itu, siswa merasakan kesulitan dalam menentukan tema karena merasa sulit untuk menemukan tema yang menarik untuk ditulis.

Kesulitan selanjutnya yaitu kesulitan kesulitan mengawali dan mengembangkan ide dan gagasan ke dalam sebuah teks. Setelah siswa menemukan tema yang akan dijadikan sebuah teks anekdot, siswa sering kesulitan untuk mengawali dan mengembangkan ide yang telah ada dalam fikirannya untuk dituangkan dituangkan ke dalam bentuk tulisan. Serta siswa sering kebingungan dalam mengungkapkan suatu gagasan dari ide tersebut ini. Hal ini senada dengan pendapat priyatna (2011:9), yang mengatakan bahwa beberapa penyebab rendahnya keterampilan menulis siswa yaitu faktor kesulitan siswa dalam mengembangkan 
ide, gagasan, kurangnya minat siswa dalam pembelajaran menulis karena adanya anggapan menulis adalah kegiatan yang membosankan dan sangat sulit. Selain itu, kurangnya waktu yang sudah ditentukan dalam pembelajaran mengarang, ini terbukti para siswa tidak dapat menyelesaikan hasil karangan secara lengkap.

Selain kesulitan mengawali dan mengembangkan ide dan gagasan, siswa juga mengalami kesulitan mencari inspirasi karena siswa sering merasa "buntu" di tengah jalan. Terkadang di tengah-tengah perjalanan dalam menulis teks anekdot, siswa sering merasa "buntu" dan tidak tahu lagi apa yang harus dituliskan. Hal ini membuat siswa kesulitan dalam melanjutkan menulis teks ankedot karena inspirasi-inspirasi atau kreativitas siswa dalam menulis teks ankedot sering terganggu. Hal ini senada dengan pendapat penelitian (Sholekah dan Nuryatin, 2016:43) menyatakan bahwa salah satu kesulitan siswa dalam menulis teks anekdot adalah siswa sering kesulitan mencari inspirasi karena siswa sering merasa "buntu" di tengah jalan dalam menulis teks ankedot. Siswa kebingungan apa yang harus dituliskan lagi, karena kehabisan inspirasi atau kata-kata di dalam fikirannya.

Kesulitan selanjutnya adalah kesulitan dalam menentukan kaidah kebahasaan. Hal ini dibuktikan dalam hasil wawancara siswa yang menunjukkan bahwa siswa mengalami kesulitan dalam menentukan kaidah kebahasaan terutama dalam menentukan kalimat langsung dan kalimat tidak langsung. Siswa sering kebingungan dalam menempatkan kalimat langsung dan kalimat tidak langsung dalam menulis teks ankedot. Hal senada dengan penelitian yang dilakukan oleh Izzati (2016:4) yang menyatakan sebagian besar siswa kesulitan dalam memahami struktur dan kaidah teks anekdot. Kesulitan siswa menentukan kaidah teks anekdot salah satunya yaitu kalimat langsung dan tidak langsung, siswa kebingungan dalam menentukan hal tersebut.Hal tersebut menjadikan siswa kesulitan untuk menentukan struktur dan kaidah teks anekdot secara tepat dan jelas.

Kesulitan lain selain kaidah kebahasan adalah juga kesulitan dalam memahami mengenai struktur teks anekdot. Hal ini terbukti dalam hasil wawancara siswa yang menujukkan bahwa siswa dalam menulis teks ankedot seringkali tidak sesuai dengan struktur anekdot dan terkadang teks ankedot yang dihasilkan siswa sering tidak lengkap strukturnya. Hal ini terjadi siswa belum memahami betul struktur teks ankedot sehingga siswa kebingungan dalam menetapkan struktur teks ankedot dalam tulisannya. Pardiyono (2008: 295) menyatakan bahwa struktur teks anekdot terdiri atas (1) abstraksi, pernyataan ekslamasif yang berkaitan dengan topik yang dituangkan dalam judul; (2) orientasi, pendahuluan atau pengantar tentang kejadin konyol yang akan diceritakan; (3) krisis; inti dari kekonyolan kejadian yang menimpa atau dialami; (4) reaksi, tindakan atau langkah yag 
diambil untuk merespon masalah, (5) koda, bagian akhir dari teks anekdot. dalam bagian ini, penulis anekdot memberi kesimpulan tentang kejadian yang dialami penulis atau orang yang ditulis. Koda juga berisi perubahan yang terjadi pada tokoh atau pelajaran yang dapat dipetik dari cerita. Kelima struktur teks ankedot tersebut yang sering tidak ada dalam tulisan siswa adalah bagian krisis dan reaksi. hal ini menunjukkan bahwa belum memahami betul tentang struktur teks ankedot.

Kesulitan berikutnya adalah kesulitan mengunakan bahasa yang santun. salah satu kesulitan siswa dalam menulis teks ankedot juga berkaitan dengan menggunakan bahasa yang santun. siswa sering kali menggunakan diksi yang tidak tepat dalam tulisannya dan tata bahasa yang digunakan juga kurang baik. hal ini menyebabkan siswa kesulitan dalam menggunakan bahasa yang santun ketika menulis teks ankedot. Menurut Moeliono (dalam Sauri 2003:47) menyatakan bahwa bahasa santun berkaitan dengan tata bahasa dan pemilihan kata. Kesantunan dalam tuturan juga memiliki beberapa indikator kesantunan lain. Salah satu indikator-indikator yang dapat digunakan adalah indikator kesantunan yang dilihat dari diksi tuturan. Pranowo (2009:104) menyatakan bahwa pemakaian kata-kata tertentu sebagai diksi yang dapat mencerminkan rasa santun kata-kata tersebut antara lain adalah sebagai berikut (1) kata "tolong" untuk meminta bantuan orang lain, (2) kata "terima kasih" seba- gai penghormatan atas kebaikan orang lain, (3) kata "maaf " untuk tuturan yang diperkirakan dapat menyinggung orang lain, (4) kata "berke- nan" untuk meminta kesediaan orang lain untuk melakukan sesuatu, (5) kata "beliau" untuk me- nyebut orang ketiga yang lebih dihormati, dan (6) kata "bapak/ ibu" untuk menyebut orang kedua yang dewasa.

Kesulitan terakhir yang dialami oleh siswa dalam menulis teks anekdot yaitu kesulitan menentukan kata sindiran yang sesuai dan tepat. Selain kesulitan menentukan bahasa yang santun siswa juga mengalami kesulitan dalam menentukan kata-kata sindiran yang tepat. Seperti diketahui teks ankedot bertujuan untuk menyindir atau sebagai sarana untuk mngkritik. Hal ini senada dengan (Kosasih, 2014:2) yang menyatakan bahwa teks anekdot selain berbentuk cerita, di dalamnya mengandung humor, kritik sekaligus berbentuk sindiran. Hal ini siswa kesulitan dalam menggunakan kata-kata sindiran yang sesuai dan tepat dalam menulis teks anekdot.

Ketidakberhasilan siswa dalam belajar di sekolah tidak senantiasa berhasil karena sering kali ada hal-hal yang bisa mengakibatkan adanya kesulitan belajar siswa. Bahkan halhal tersebut bisa menimbulkan kegagalan atau setidaknya menjadi gangguan yang bisa menghambat kemampuan belajar siswa. Hamalik (2005:117) mengemukakan beberapa 
faktor yang bisa menimbulkan kesulitan belajar pada siswa pada umumnya. Adapun faktor-faktor yang bisa menimbulkan kesulitan itu dapat digolongkan menjadi: (1) faktorfaktor yang bersumber dari diri sendiri, (2) faktor-faktor yang bersumber dari lingkungan sekolah, (3) faktor-faktor yang bersumber dari lingkungan keluarga, dan (4) faktor-faktor yang bersumber dari lingkungan masyarakat.

Berdasarkan data hasil penelitian ada tiga faktor yang menjadi penyebab adanya kesulitan belajar yang dialami oleh siswa kelas X IPS2 SMA Negeri 2 Percut Sei Tuan Medan. Faktor yang pertama yaitu yang bersumber dari lingkungan sekolah. Kesulitan belajar yang dialami oleh siswa bisa saja bersumber dari banyak hal. Salah satunya yaitu lingkungan sekolah atau lembaga tempat siswa belajar untuk menuntun ilmu. Hamalik (2005:117) mengemukakan hambatan terhadap kemajuan studi tidak saja bersumber dari diri siswa itu sendiri, akan tetapi kemungkinan juga bersumber dari sekolah atau lembaga itu sendiri. Berdasarkan hasil observasi, guru dalam memberikan bimbingan saat siswa mulai melakukan pembelajaran terutama dalam dalam kegiatan menulis, guru tidak sampai tuntas membimbing siswa dalam belajar. hal ini juga terbukti dari hasil wawancara siswa yang menyatakan bahwa guru tidak pernah sampai selesai membimbing dalam kegiatan menulis khusunya ketika menulis teks anekdot. Hal ini menjadi salah satu penyebab adanya kesulitan siswa. Apalagi bagi siswa, pembelajaran teks anekdot baru pertama kalinya dipelajari pada jenjang SMA dan termasuk pembelajaran yang baru di kurikulum 2013. Hal ini senada dengan pendapat Hamalik (2005:117) yang mengatakan bahwa cara yang digunakan oleh pengajar dalam memberikan pelajar dan bimbingan sering kali besar pengaruhnya terhadap siswa dalam kesuksesan belajarnya. Serta menurut Yamin (2009: 130) menyatakan bahwa Belajar tuntas merupakan proses pembelajaran yang dilakukan dengan sistematis dan terstruktur, bertujuan untuk mengadaptasikan pembelajaran pada sisiwa kelompok besar (pengajaran klasikal), membantu mengatasi perbedaan-perbedaan yang terdapat pada siswa dan berguna untuk menciptakan kecepatan belajar. jadi, dapat dikatakan kurangnya bimbingan dari guru akan menimbulkan adanya kesulitan belajar yang dialami oleh siswa dalam proses pembelajaran.

Selain kurangnya bimbingan dari guru, faktor lain yang juga bersumber dari lingkungan sekolah yaitu sekolah belum pernah memberikan dukungan dalam kegiatan menulis teks anekdot. Sekolah belum menciptakan iklim yang kondusif bagi pembelajaran menulis teks ankedot. Misalanya dengan mewajibkan siswa mengikuti perlombaanperlombaan lomba menulis khususnya menulis teks ankedot yang diadakan oleh lembaga pendidikan lainnya seperti universitas atau lembaga yang lainnya. Meskipun sekolah SMA 
Negeri 2 Percut Sei Tuan Medan masih terbilang baru beroperasional dalam pendidikan di kota medan, karena baru diresmikan tahun 2015. Hal ini tidak menjadi alasan untuk sekolah tidak bisa mengadakan lomba-lomba menulis atau mewajibkan siswanya untuk mengikuti perlombaan di luar. Selain menambah pengetahuan siswa dalam kegiatan menulis, hal ini juga akan bisa membangkitkan dan mengenalkan nama sekolah ke masyarakat yang belum mengetahuinya.

Faktor lain yang menjadi penyebab kesulitan belajar yang dialami oleh siswa yaitu faktor yang bersumber dari lingkungan keluarga siswa. Keluarga merupakan pusat pendidikan yang utama dan pertama, tetapi dapat juga sebagai faktor penyebab kesulitan belajar. sebagaimana yang diungkap oleh Amti (dalam Haryatni, 2014:10) yang menyatakn bahwa pendidikan itu tidak hanya berlangsung di sekolah tetapi juga dalam lingkungan keluarga. Oleh karena itu, aspek-aspek kehidupan dalam keluarga turut memengaruhi kemajuan studi siswa. Berdasarkan data hasil penelitian, siswa tidak pernah mendapatkan dukungan dan perhatian dari keluarga dalam belajar terutama dalam kegiatan menulis, khusunya menulis teks anekdot. Kemudian dari hasil wawancara siswa menyatakan bahwa mereka tidak pernah ada dukungan dari keluarga untuk mengikuti lomba-lomba menulis utamanya menulis teks ankedot. Tentu saja jika tidak adanya dukungan dari orang tua mereka tersebut menjadi salah satu faktor penyebab siswa mengalami kesulitan belajar sehingga tidak adanya kemajuan dalam studi siswa itu sendiri. Hal ini senada dengan pendapat Hamalik (2005:117) yang mengatakan bahwa kurangnya kontrol orang tua merupakan salah satu faktor penyebab kesulitan belajar yang bersumber dari lingkungan keluarga. menurut hasil penelitian Febriany, dan Yusri (2013) bahwa terdapat hubungan yang signifikan perhatian orangtua dengan motivasi belajar siswa dalam mengerjakan tugas-tugas sekolah. Jadi, terbukti bahwa faktor keluarga sangat berpengaruh dalam tercapainya belajar siswa.

Faktor yang terakhir yaitu faktor yang bersumber dari lingkungan masyarakat. hal ini Menurut Kartono (dalam Haryetni, 2014) menyatakan bahwa salah satu faktor eksternal penyebab kesulitan dalam belajar, selain lingkungan keluarga dan lingkungan sekolah, faktor lingkungan sosial atau masyarakat juga sebagai penyebab kesulitan belajar pada siswa. Hamalik (2015:117) juga mengatakan bahwa kehidupan di masyarakat juga dapat menjadi salah satu faktor yang menyebabkan adanya kesulitan belajar pada siswa. Hal ini bisa menjadi faktor penyebab kesulitan belajar karena siswa juga menghabiskan sebagian waktunya untuk bergaul dengan lingkungan masyarakatnya. Berdasarkan data hasil penelitian, salah satu faktor penyebab dari lingkungan sosial atau masyarakat yang dialami oleh 
siswa kelas XIPS 2 SMA Negeri 2 Percut Sei Tuan Medan yaitu lingkungan masyarakat tidak pernah mendukung kegiatan akademis siswa. Bahkan tidak pernah peduli dan memperhatikan anak-anak sekolah di lingkungan masyarakat tempat siswa tinggal. Dalam hal ini adalah kegiatan tulis-menulis, salah satunya yaitu kegiatan menulis teka anekdot. Misalnya dengan mengadakan lomba menulis teks anekdot tingkat kampuang atau desa. Tidak pernahnya lingkungan memotivasi atau memberian perhatian kepada siswa melalui kegiatan akademis, tentu hal ini akan membuat siswa mengalami kesulitan dalam belajar terutama dalam kegiatan menulis khususnya menulis teks ankedot.

Dengan adanya kesulitan dan faktor-faktor penyebab kesulitan yang dialami oleh siswa kelas X IPS 2 SMA Negeri 2 Percut Sei Tuan Medan tersebut. Peneliti merasa kesulitan tersebut lumrah terjadi, karena akan ada kesulitan belajar yang akan dialami oleh pada keterampilan menulis teks anekdot. Hal tersebut karena empat keterampilan berbahasa (menyimak, berbicara, membaca dan menulis) merupakan keterampilan yang tidak tidak mudah untuk dikuasai dan sangat sulit bagi siswa dalam menguasainya. Siswa akan selalu megalami kesulitan dalam belajar, terutama pada pembelajaran yang berkaitan dengan keterampilan berbahasa . hal itu terlihat dalam penelitian sejenis berikut ini.

Kesulitan dan faktor penyebab kesulitan belajar dalam keterampilan berbahasa yang dialami oleh siswa juga ditemukan oleh Dewantara (2012). Dalam penelitiannya, Dewantara menemukan ada sembilan faktor penyebab kesulitan belajar keterampilan berbicara yaitu motivasi, kebiasaan belajar, penguasaan komponen kebahasaan, penguasaan komponen isi, sikap mental, hubungan/interaksi guru dan siswa, metode pembelajaran, media pembelajaran, dan hubungan/interaksi antara siswa dan siswa.selain itu, kesulitan belajar dan faktor penyebab kesulitan belajar dalam keterampilan berbahasa ditemukan juga oleh Indra (2014). Indra menemukan adanya kesulitan-kesulitan belajar dalam keterampilan menulis dan faktor penyebabnya. Kesulitan tersebut adalah kesulitan-kesulitan dalam memproduksi tulisan grafemis

selanjutnya dari penelitian yang dilakukan oleh Selawati ( 2016) penelitian ini menyimpulkan bahwa faktor-faktor yang berpengaruh terhadap kesulitan belajar siswa dalam pembelajaran keterampilan berbicara siswa berasal dari faktor dalam ( internal ) dan faktor luar ( eksternal ), yaitu (1) motivasi belajar siswa yang masih rendah; (2) kebiasaan belajar siswa yang kurang baik; (3) penguasaan komponen kebahasaan masih rendah; (4) sikap mental siswa kurang baik; (5) hubungan/interaksi guru dan siswa masih rendah; (6) hubungan/interaksi siswa dengan siswa masih rendah; (7) media mengajar guru kurang menarik dan; (8) media pembelajaran yang belum dimanfaatkan oleh guru. 
Pada penelitian ini, peneliti hanya meneliti kesulitan dan faktor penyebab kesulitan belajar keterampilan menulis teks anekdot siswa kelas X IPS 2 SMA Negeri 2 Percut Sei Tuan Medan. Karena keterbatasan peneliti, masih ada yang luput dari penelitian ini. Dengan terbukti adanya kesulitan dan faktor penyebab kesulitan yang dialami oleh siswa kelas X IPS 2 SMANegeri 2 Percut Sei Tuan medan, maka harus ada solusi atau strategi untuk mengatasinya. Hal tersebutlah yang masih luput dari penelitian ini. Oleh karena itu, penelitian terkait dengan solusi atau strategi untuk mengatasi kesulitan belajar keterampilan menulis teks ankedot perlu untuk dilakukan. Mengingat setiap kesulitan belajar siswa dan faktor penyebabnya harus bisa diatasi guna tercapainya tujuan belajar.

\section{SIMPULAN DAN SARAN}

Kesulitan belajar keterampilan menulis teks anekdot yang dialami oleh siswa kelas X IPS 2 SMA Negeri 2 Percut Sei Tuan Medan meliputi tujuh kesulitan yaitu Kesulitan tersebut yaitu (a) kesulitan dalam menentukan tema yang menarik, (b) kesulitan mengawali dan mengembangkan ide dan gagasan ke dalam sebuah teks (c) kesulitan mencari inspirasi karena siswa sering merasa "buntu" di tengah jalan, (d) kesulitan dalam menentukan kaidah kebahasaan, (e) kurang memahami mengenai struktur teks anekdot, (f) kesulitan mengunakan bahasa yang santun, dan (g) kesulitan menentukan kata sindiran yang sesuai dan tepat.

Kesulitan belajar yang dialami oleh siswa kelas X IPS 2 SMA Negeri 2 Percut Sei Tuan Meda dikarenakan oleh beberapa faktor. Pertama, faktor yang bersumber dari lingkungan sekolah. Ada dua hal yang menjadi faktor penyebab kesulitan belajar yang bersumber dari lingkungan sekolah yaitu kurangnya bimbingan secara langsung oleh guru saat siswa menulis teks anekdot dan sekolah yang tidak menciptakan iklim yang kondusif bagi siswa untuk menuangkan kemampuan atau kreatifitas sekolahnya dalam mengadakan lomba-lomba menulis khsusnya lomba menulis teks anekdot. Kedua, faktor yang bersumber dari faktor lingkungan keluarga. siswa tidak pernah mendapatkan dukungan dan perhatian dari keluarga dalam belajar terutama dalam kegiatan menulis. Jika tidak ada dukungan perhatian yang lebih dari keluarga tentu ini akan menjadi penyebab kesulitan belajar siswa. Ketiga, kesulitan dari faktor lingkungan masyarakat yaitu lingkungan masyarakat tidak pernah mendukung kegiatan akademis siswa. Bahkan tidak pernah peduli dan memperhatikan anak-anak sekolah di lingkungan masyarakat tempat siswa tinggal. Misalnya mengadakan lomba-lomba menulis khusunya tingkat kampung atau desa di lingkungan tempat tinggal siswa. 
Berdasarkan hasil penelitian dan simpulan di atas, ada tiga saran yang dapat disampaikan dalam penelitian ini. Pertama, saran yang ditujukan untuk guru Bahasa Indonesia yaitu menggunakan hasil penelitian ini sebagai dasar tindak lanjut untuk pembelajaran keterampilan menulis teks ankedot agar siswa lebih mengenal dan memahami tingkat pengetahuannya tentang menulis teks anekdot. Kedua, saran yang ditujukan untuk sekolah yaitu hasil penelitian ini dapat direkomendasikan untuk dibaca oleh guru-guru bahasa Indonesia agar dapat melakukan pembelajaran menulis teks anekdot dengan lebih baik agar siswa bisa lebih mengerti dan paham dalam menulis teks ankedot termasuk struktur-struktur serta kaidah kebahasaannya. Ketiga, saran untuk mahasiswa calon guru yaitu hasil penelitian ini dapat digunakan sebagai bahan masukan untuk melaksanakan pembelajaran keterampilan menulis teks ankedot, khususnya pada siswa kelas X SMA Negeri 2 Percut Sei Tuan Medan. Keempat, saran untuk peneliti lain yaitu Penelitian ini meneliti mengenai kesulitan belajar keterampilan menulis teks anekdot yang dialami oleh siswa. Ada tujuh kesulitan dan tiga faktor penyebab kesulitan belajar yang dialami siswa saat menulis teks anekdot. Dengan demikian, disarankan kepada peneliti lain untuk mengadakan penelitian mengenai solusi atau strategi untuk mengatasi kesulitan belajar dan faktor penyebab kesulitan belajar keterampilan menulis teks anekdot. 


\section{DAFTAR PUSTAKA}

Akhdiah, Sabarti. 2003. Pembinaan Kemampuan Menulis Bahasa Indonesia. Jakarta: Penerbit Erlangga.

Akhadiah, Sabarti, Maidar, G. Arsyad, \& Sakura, H. Ridwan. 1988. Pembinaan Kemampuan Menulis Bahasa Indonesia. Jakarta: Erlangga.

Abdurrahman, Mulyono. 1999. Pendidikan Bagi Anak Berkesulitan Belajar. Jakarta: Rineka Cipta.

Dewantara, I Putu Mas. 2012. Indentifikasi Faktor Penyebab Kesulitan Belajar

Keterampilan Berbicara Siswa Kelas VIIE SMPN 5 Negara dan Strategi Guru Untuk Mengatasinya. Artikel Prodi Pendidikan Bahasa, Mei 2012.

Febriany, Rani dan Yusri. 2013. Hubungan Perhatian Orang Tua dengan Motivasi Belajar Siswa dalam Mengerjakan Tugas-Tugas Sekolah. Jurnal Ilmiah Konseling, volume 2 nomor 1, Januari 2013.

Ghazali, Syukur. 2013. Pembelajaran Keterampilan Berbahasa Dengan Pendidikan Komunikatif-Interaktif. Bandung: PT Refik.

Gunatama, I Gede. 2005. Teori Sastra. Singaraja: Undiksha.

Hamalik, Oemar. 2005. Metoda Belajar dan Kesulitan-Kesulitan Belajar. Bandung: Tarsito. Haryetni, Anggina Pratiwi. 2014. Identifikasi Faktor-Faktor Kesulitan Belajara Pada Siswa SMP Negeri 5 Kota Jambi (Skripsi). Jambi: Fakultas Keguruan dan Ilmu Pendidikan, Universitas Jambi.

Izzati, Laila Nur. 2016. Pembelajaran Memahami Struktur dan Kaidah Teks Anekdot dengan Menggunakan Metode Planted Quesyion Pada Siswa Kelas X SMA PGRI 1 Bandung Tahun Pelajaran 2016/2017 (Skripsi). Bandung: Fakultas Keguruan dan Ilmu Pendidikan, Universitas Pasundan.

Kosasih, E. (2014). Jenis-jenis Teks (Analisis Fungsi, Struktur, dan Kaidah serta Langkah Penulisannya). Bandung: Yrama Widya.

Maryaeni. 2005. Metode Penelitian Kebudayaan. Jakarta: Bumi aksara.

Mulyasa. 2013. Pengembangan dan Implementasi Kurikulum 2013. Bandung: PT Remaja Rosdakarya.

Pardiyono. 2008. Teaching Genre-Based Writing. Yogya- karta: Penerbit Andi. Pranowo. 2009. Berbahasa Secara Santun. Yogyakarta: Pustaka Pelajar. 
Priyatna, Agustian. 2011. Peningkatan Keterampilan Menulis Karangan Narasi Menggunakan Metode Pembelajaran Kooperatif Tipe STAD Pada Siswa Kelas VII SMP Muhammadiyah Sadang Kebumen (skripsi).

Rachmawati, Elin Nur. 2014. Peningkatan Keterampilan Menulis Anekdot Menggunakan Strategi Genius Learning untuk Siswa Kelas X Kendaraan Ringan (KR) 3 SMK Negeri 3 Yogyakarta (Skripsi). Yogyakarta: FBS UNY.

Sauri, Sofyan. 2003. Pengembangan Strategi Pendidi- kan Berbahasa Santun Di Sekolah. Universitas Pendidikan Indonesia: Mimbar Pendidikan.

Selawati, Trian Siam. 2016. Identifikasi Penyebab Kesulitan Belajar Keterampilan Berbicara Siswa. Fakultas Ilmu Pendidikan, Universitas Negeri Yogyakarta.

Sholekah, Lies Aryanti Nur dan Agus Nuryatin. 2016. Peningkatan KeterampilanMenulis Teks Anekdot Bermuatan Kesantunan Berbahasa Menggunakan Model Pembelajaran Berbasis Masalah (Problem Based Learning) Pada Siswa Kelas X MIA4 SMA Negeri 1 Grobogan Tahun Ajaran 2013/2014.Jurnal Pendidikan Bahasa dan Sastra Indonesia, volume 05 nomor o1, Mei 2016.

Sugiyono. 2007. Metode Penelitian Pendidikan Pendekatan Kuantitatif Kualitatif dan $R \& D$.Bandung: Alfabeta.

Tarigan, Henry Guntur. 2008. Menulis sebagai Suatu Keterampilan Berbahasa. Bandung: Angkasa.

Taufik, Indra Nugrahayu. 2014. Kajian Kesulitan Belajara Menulis Pada Siswa Kelas II Sekolah Dasar Negeri 2 Cihalimun Kec. Kertasari Kab. Bandung. Jurnal Pendidikan Bahasa dan Sastra Indonesia.

Wardani, Sefri Rahma, Amir Fuady dan Andayani. 2016. Peningkatan Keaktifan Menulis Teks Anekdot dengan Menggunakan Model Pembelajaran Make A Match pada Siswa Kelas X SMK. Jurnal Penelitian Bahasa, Sastra Indonesia dan Pengajarannya, volume 4 nomor 1, April 2016.

Yamin, Martinis. 2009. Desain Pembelajaran Berbasis Tingkat Satuan Pendidikan. Jakarta: Gaung Persada. 